\title{
Analyzing EFL University Learners' Positionings and Participation Structures in a Collaborative Learning Environment
}

\author{
Análisis de posicionamientos y estructuras de \\ participación de un grupo de aprendices universitarios \\ de inglés en un ambiente de aprendizaje colaborativo
}

\author{
Aida Montenegro \\ Universidad Minuto de Dios \\ Bogotá, Colombia \\ E-mail: aidamilenamontenegro@gmail.com
}

Received: 18 - Nov - 11 / Accepted: 16 - May - 12

\begin{abstract}
A preliminary analysis about the way a group of university students behaved in group activities that promoted interaction and negotiation revealed that some students were positioned negatively while learning English. This qualitative study analyzed the learners' positionings as group members and the participation structures under a specific pedagogical intervention focused on peer collaboration. The data collection instruments were audio recordings, field notes and individual conferences. The conclusions show that the rights and responsibilities during group work were given according to the way the learners mutually acknowledged their skills. The school and social skills recognized by the peers were related to checking each others' work, building consensus, and guiding the development of the task.
\end{abstract}

Keywords: Positioning, Participation Structures and Collaborative Learning

\section{Resumen}

Un análisis preliminar sobre el comportamiento de un grupo de aprendices universitarios de inglés reveló que algunos estudiantes eran posicionados negativamente durante el trabajo grupal que requería interacción y negociación. Este estudio cualitativo se centró en el análisis de los posicionamientos y las estructuras de participación en grupo durante una intervención pedagógica basada en colaboración. Los instrumentos de recolección de datos fueron grabaciones de voz, notas de campo y conferencias. Las conclusiones muestran que los derechos y las responsabilidades dependían de la forma en que los aprendices mutuamente reconocían sus habilidades, las cuales se relacionan con revisar el trabajo de los compañeros, llegar a consensos, y guiar el desarrollo de las actividades en grupo.

Palabras clave: Posicionamiento, Estructuras de Participación y Aprendizaje Colaborativo 


\section{Introduction}

This qualitative research was designed under the idea that there is a need to understand positionings (the way people discursively position themselves and others) and participation structures (the framework in which people structure rights and responsibilities during group work) in a learning environment focused on collaboration.

For the purpose of understanding the learners' group interaction and participation in English class, this study combined two data analysis methods: Conversational Analysis (CA) and Transactional Analysis (TA). CA "is the systematic analysis of the talk produced in everyday situations of human interaction" (Hutchby \& Wooffitt., 2008, p. 11), and TA is a theory that offers a "useful model for understanding the nature of interpersonal relationships" (Hayes, 2002, p. 294). In order to explore my participants' linguistics choices and describe their peer-to-peer transactions during the group work, I developed a series of steps to understand the way they positioned themselves and their classmates as members of a group in a Collaborative Learning environment. The pedagogical intervention for this study included specific activities that promoted peer interaction, negotiation and collaboration.

After observing my students during the first month of the academic semester, I concluded that some classmates were ignored at the moment of negotiating ideas or responsibilities during the development of a group activity. Even though non-participative students did not tend to interrupt the tasks, the fact that their voices were not heard in class, or even worse, that they were ignored by their classmates, was truly a cause for concern. Indeed, the first written and oral evaluations of these non-participative English students were not satisfactory.
With the purpose to explore more about what my students thought when they participated in groups, I administered a questionnaire. The results showed that the reasons why some learners did not participate in groups were related to the fear of making mistakes in English and disinterest in assuming responsibilities as members of the group. The results about the reactions when a team member did not participate revealed that $50 \%$ (1) tried to encourage the person, (2) $40 \%$ try, -after encouraging him/her to participatetried to confront him/her by asking why they did not participate in the group activity, and 3) $10 \%$ of the participants tried to ignore or ask the person to get out of the group.

Summarizing the key aspects of my students' answers and my own observations, I identified that half of my students had a negative perception about their non-participative classmates who also obtained a low score on their first individual tests - as people who lack commitment, motivation and English knowledge.

Bearing in mind that "there is a need to understand how language learners' interactions are structured and how power relationships are (re)produced in particular social practices" (Miller, 2007, p. 120) and based on the learners' needs analysis carried out, the statement of the problem of this study is framed by the need to understand students' positionings as members of a group and their participation structures in an EFL learning environment. These positionings may maintain, minimize, maximize or eliminate either favorable or unfavorable behaviors among learners, and they may influence the participation structures in an EFL learning process.

Taking into consideration the analysis of my participants' context and my learners' needs analysis, I posed the following research questions and objectives related to positioning and participation structures in an EFL learning environment: 
Table 1: Research questions and objectives of this study

\begin{tabular}{|c|c|c|}
\hline $\begin{array}{l}\text { Research } \\
\text { questions }\end{array}$ & $\begin{array}{c}\text { How do EFL University students position } \\
\text { themselves and their classmates as mem- } \\
\text { bers of a group in a learning environment } \\
\text { that promotes peer collaboration? }\end{array}$ & $\begin{array}{c}\text { What do these positionings tell us } \\
\text { about participation structures in a } \\
\text { learning environment that pro- } \\
\text { motes peer collaboration? }\end{array}$ \\
\hline $\begin{array}{c}\text { Research } \\
\text { objectives }\end{array}$ & $\begin{array}{c}\text { To describe the type of positionings students } \\
\text { adopt or assign to one another in a learning } \\
\text { environment that promotes peer collabora- } \\
\text { tion }\end{array}$ & $\begin{array}{c}\text { To analyze the relationship be- } \\
\text { tween these positionings and their } \\
\text { participation structures in a learn- } \\
\text { ing environment that promotes } \\
\text { peer collaboration }\end{array}$ \\
\hline
\end{tabular}

The exploration of the way learners position themselves and their peers as group members and their participation structures was relevant not only for the participants, who could reflect upon their discourse and behavior, but also for me as a teacher-researcher. Thanks to this analysis, I could reflect upon the way I explained the instructions in group activities, the nature of a group activity, the rights and responsibilities during group work, the way my students positioned themselves as group members and their participation structures during group work.

This qualitative research provides an alternative to explore discourse and human behavior. This study describes how Conversational Analysis and Transactional Analysis may contribute to exploring positionings and participation structures in group activities. Through this study, other researchers will have the opportunity to know how to interpret learners' discourse through the use of a mixed data analysis method. This study also invites teachers to be more aware about the group activities they assign and the variety of positionings that can emerge during group work.

This part deals with the theoretical underpinnings of collaborative learning, positioning and participation structures. The concept of positioning was analyzed, allowing me to better understand how people position themselves and others discursively, especially as members of a group. Having explored the concepts of a collaborative learning environment and positioning, participation structures were defined from a socio-psychological perspective.

\section{Collaborative Learning Environment}

In 1978, Vygotsky extended the term "cognitive constructivism", claiming the importance of social context for learning (Stauffacher et al., 2006). Vygotsky's understanding about learning through interaction allowed him to introduce what was later termed "social constructivism". Wilson and Myers (2000 in Stauffacher et al., 2006) describe this learning as a process of mutually developing a shared understanding. For them, "construction of meaning is tied to specific contexts and purposes. People develop shared ways of responding to patterns and features in particular contexts" (p. 69). There is a huge variety of realizations of socio-cultural constructivism in education (Stauffacher et al., 2006), among which I would like to highlight the negotiation and interpretation of personal beliefs.

I strongly believe that learning depends on negotiation. Based on this idea, the instructional design of this research was based on Collaborative Learning (CL). As Golub (1988) points out in Smith and MacGregor (1992), CL allows students to talk with each other, and it is in this 
talking that much of the learning may occur. This mutual exploration among peers often leads to better understanding. According to Smith and MacGregor (1992), CL "is both socially and intellectually involving" because "it invites students to build closer connections to other students, their faculty, their courses and their learning" (p. 3). Enhancing social skills through group activities that promote collaboration was a purpose of the instructional design of this study.

Collaborative learning activities "immerse students in challenging tasks or questions" (Brown, Collins \& Duguid, 1989 in Smith \& MacGregor, 1992). Students-generated questioning is a key component of rich classroom contexts that challenge learners to interact and collaborate among themselves. It is the process by which a learner reports possible findings and poses questions in regards to a topic. This type of activity has been highly related to reading comprehension. The first training studies on student-generated questions date from the 1960s (Janssen et al., 2009, p. 671). Since then, ample research has revealed different benefits where students are motivated to generate questions, especially during and after the reading of texts. Student-generated questioning was an important step in the pedagogical design of this study in order to promote collaboration while learning English as a foreign language.

To conclude, "no communication would be possible without convergent and dynamic negotiation of meaning, without the creation and adequate interpretation of meaning" (Jauregi, 1997, p. 113). When we engage in conversation, we are constantly positioning ourselves and others on a turn by turn-by-turn process. There is a need to explore the processes of positioning as group members in EFL learning environments.

\section{Positioning}

According to Harré and Moghaddam (2003), positioning refers to the cluster of rights and duties to perform specific actions. For these authors, there are indirect positionings (also called presumptive positioning) that portray people favorably or unfavorably according to their mental (e.g. stupid), characterological (unreliable), or moral (puritanical) characteristics. The authors exemplify that if a person positions another as stupid, she/he is denying the other the right to correct one's cognitive performances. Based on this idea, there are two extreme forms of the process of positioning: one that is planned and executed deliberately, and one that is socially constructed as part of the natural order of the social system. This means we either position ourselves and others intentionally as community members because we have a particular interest, or the positioning emerges from a need to become part of a society.

Positioning refers to an internal process that is exteriorized through discourse. Positioning, defined as "the dynamic construction of personal identities relative to those of others", is "an essential feature of social interaction (Davies E Harré, 1990 in Parrott, 2003, p. 29). This dynamic construction is analyzed by describing and interpreting the participants' discourse. In this study, positionings were analyzed by taking into consideration the description of three ego states (Child-Adult-Parent) proposed by Transactional Analysis Theory. In other words, for the analysis of positionings, I started by analyzing the participants' linguistics choices and the characteristics of each ego state during peer interaction from a transactional perspective.

Transactional Analysis focuses on three ego states and studies how people interact with each other from within these states. According to Berne (1964 in Hayes, 2002), the ego state that predominates determines behavior. The idea of analyzing how ego states play out with others was developed progressively under the name of Structural Analysis - a branch of Transactional Analysis. 


\section{Participation Structures in a Classroom Setting}

Participation structure refers to "the rights and obligations of participation with respect to who can talk and when in any social event" (Philips, 1972 in Johnson, 2002, p. 41). In 1982, Erickson argued that successful participation in classroom events requires that learners perceive the subject and the social organization of participation (Johnson, 2002).

According to Gaventa and Jethro (2010), to assess the extent to which participation can occur, it is necessary to examine what we mean by power. Hayward (1998) in Gaventa and Jethro (2010), understands power as the network of social boundaries that delimit fields of possible actions. For this author, freedom is the capacity to participate in shaping the social limits. In this sense, participation as freedom is not only the right to participate effectively in a given space but also the right to define and shape that space and the scope for possible actions within it (Gaventa $\mathcal{E}$ Jethro, 2010). For these authors, power relations help shape the boundaries of participatory spaces, what is possible within them, and who may enter with which identities, discourses, and interests. According to Erickson (1982) in Johnson (2002), social participation structures represent the distribution of interactional rights and responsibilities of participants.

Goffman (1963) in Mortensen (2008) was interested in how participants in social encounters took up various roles within the interaction. He criticized the distinction between "speaker" and "hearer" for being too basic to describe the dynamic aspect of interaction. Instead, he introduced the participation framework. Participation framework "describes different roles of "hearers" according to whether the hearer is the main addressee or not, and whether ( $\mathrm{s}$ )he is a ratified participant or not" (Mortensen, 2008, p. 24). From my point of view, the participation framework or structure in the classroom is not only shaped by the participants' discourse and behavior but also the nature of the activities shared in group.

To sum up, peer interaction is understood as the interactional process among learners who share similar characteristics such as age, status, and setting. The interaction among peers was observed and audio-recorded in order to be transcribed.

\section{Method}

This research is framed within the characteristics of a qualitative study, understood as "a means for exploring and understanding the meaning individuals or groups ascribe to a social or human problem" (Creswell, 2009, p. 4). This study is also classified as a qualitative research because it is modeled on a characteristic given by Corbin (2008 in Corbin \& Strauss, 2008): the possibility (1) to get at the inner experience of the participants, (2) to determine how meanings are formed through and in culture, and (3) to discover rather than test variables.

The model of analysis was inductive (from data to theory). Inductive research "begins with specific data, which are then used to develop (induce) a general explanation (a theory) to account for the data" (Engel \& Schutt, 2009, p. 52). The data on students' positions and peer participation structures were categorized and conceptualized in order to explain the relationship among the ways students positioned themselves and its influence on their participation structures in an EFL classroom.

This study was developed at a private university in Colombia called Fundación Universitaria Los Libertadores (FULL). The university -founded in 1982 in Chapinero, Bogotá- projects itself as a social and higher 
education organization, having leadership in the use of technology, and its mission is to educate full professionals and critical citizens. The Foreign Languages Department at FULL is in charge of teaching English to all students from all disciplines, which have different intensities of the language in terms of hours and schedules.

The participants selected for convenience in terms of schedule and availability were a group of 21 university students at the pre-intermediate level in English who belonged to different undergraduate programs. They shared some characteristics in terms of their social status, experience as university students, and being pre-intermediate EFL learners who had taken standardized exams.

In order to describe and interpret how my learners positioned themselves and their peers as group members, and to better understand their participation structures in an EFL University learning environment, spoken and written data were gathered during the second academic term of the semester.

During ten classroom sessions (two per week) in the second academic term of the semester, I made audio recordings (25 minutes approximately per session) of the six small groups while talking about the development of the task. The use of English was required in the sessions; however, the groups interacted using both English and Spanish.

I also wrote field notes and applied questionnaires and conferences to determine what they thought of themselves, their classmates and the activities. The main data collection instrument was the audio recordings because the participants' discourse allowed me to identify their positionings in peer interaction. The other two instruments were complementary to the analysis. The following table shows the data collection instruments used to unveil the participants' positionings and their participation structures is group activities:

Audio recording my participants' voices during interaction was the way to gather accurate information on their patterns of interactional behavior. Even though English was required in each session, the learners used Spanish mainly to structure the development of each task. I recorded my learners' voices during the process of negotiation and collaboration in groups of three. According to Burns (1999), recording allows us to focus on "specific concerns such as pairwork interactions, the amount of learner talk generated through particular activities, or the analysis of critical incidents" (p. 94).

Teacher field notes were the second instrument for data collection. They are "descriptions and accounts of events in the research context which are written in relatively factual and objective style" (Burns, 1999, p. 87). Taking field notes requires time during and after teaching. These notes were used to describe how my learners interacted in group activities. For Burns (1999), the effect of writing observation and reflections through notes is very "illuminating as over time they build a picture of classroom participants and interactions" (p. 85).

Individual conferences were the third instrument. They allow "the interviewer to be flexible, informal, and conversational" (Babbie E Rubin, 2010, p. 102). In this research, the conferences were carried out individually taking into account specific questions for each participant based on a preliminary analysis on the recordings done during group work (see Annex 1). These conferences were in Spanish, audio recorded after explaining the purpose of the conference and lasted 20 minutes.

\section{Instructional Design}

Taking into account that collaborative learning was promoted in the sessions of this 


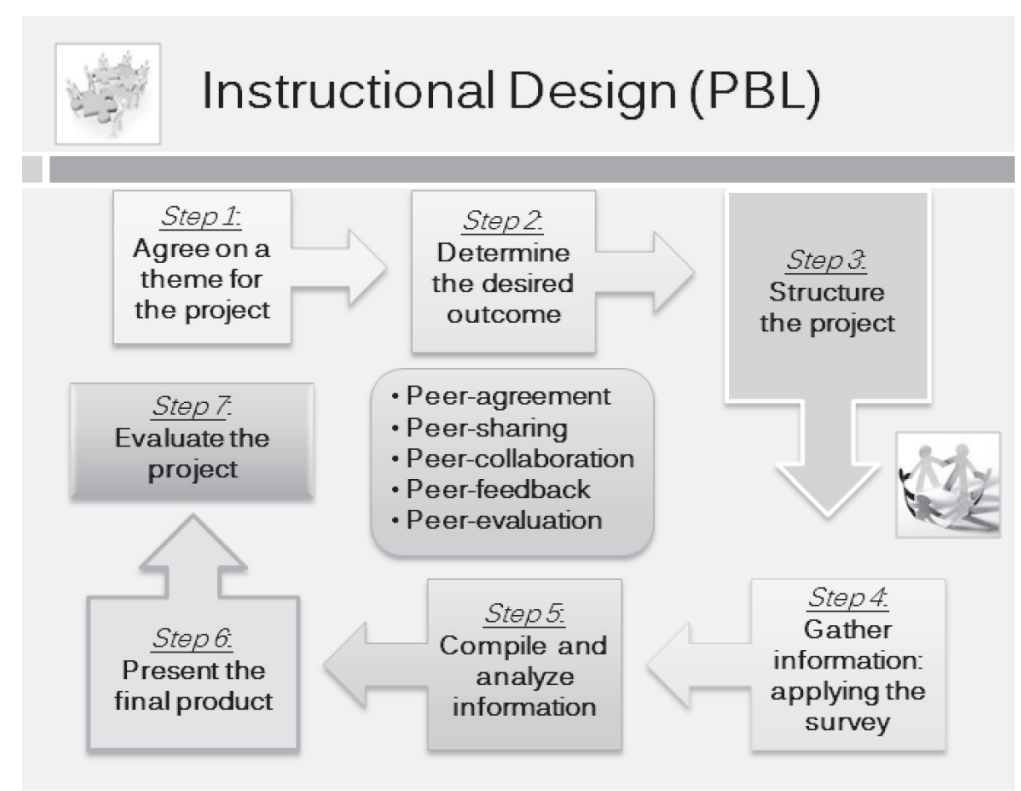

Figure 1: Steps followed when implementing the Instructional Design

study, the pedagogical intervention was designed under the assumption that collaboration is an essential activity for learning. As Dart (1998) argued, "collaborative learning groups provide opportunities for learners to examine and refine their understandings" (p. 31). The intervention of the present study was designed within the parameters of a project-based methodology.

The learners were instructed on project work before starting the activities. Given that projects can be linked to real-world concerns and tied to students' interests (Stoller, 2002) and promote peer collaboration, the following activities were included: peer agreement, peer sharing, peer collaboration, peer feedback, and peer evaluation. Seven steps of the intervention were adapted from Stoller's (2002) proposal, and the activities were designed based on the idea that peer interaction was important for the enhancement of social skills. The following steps were followed when implementing the Instructional Design:

In order to promote peer interaction, the steps depicted above were developed in small groups of three or four learners. Each group member had constant contact with me and their classmates through the Internet.

\section{Findings}

Some analytical tools employed in Conversational Analysis (CA) and Transactional Analysis (TA) were used to understand the role of linguistic choices in establishing and maintaining identity and participation within a small group. Before explaining the procedures followed to develop the findings, I will describe the two data analysis methods used in this study.

\section{Conversational Analysis and Transactional Analysis}

According to Psathas (1995 in Seedhouse, 2004), Conversational Analysis studies the order of social action in interaction. The analyst's task is "to develop an emic perspective, to uncover and describe this organization and order" (p. 12). The interest of this particular analysis is to identify the mechanism which enables people to achieve 
that organization and order (Seedhouse, 2004) and to discover how participants understand and respond to one another (Hutchby $\varepsilon$ Wooffitt, 2008).

Berne (1966) in Weisberg and Weisberg (2002) distinguished three types of transactions: complementary, crossed, and ulterior. A complementary transaction occurs when a message - sent from a specific ego state - gets a response from the same ego state in the interlocutor. A crossed transaction occurs when an inappropriate ego state is activated and the lines of communication are not parallel. In a crossed transaction, the person who initiates the transaction expects a specific reaction, but s/ he does not get it from the other person. Ulterior transactions are the most complex transactions because they involve two or more ego states within the same person. In other words, one ego state can emerge verbally and the other may be seen non-verbally, originating a possible incongruence.

For this study, crossed transactions were selected as telling cases. A telling case is a case that "allows in-depth exploration of theoretical issues not previously visible." (Dixon et al., 2000, p. 87). These telling cases provided a way of exploring when and how some messages were not understood, accepted and/or did not get a desired response during the interaction. This procedure also helped me organize the huge amount of data I gathered during the data collection process.

For this study, I designed five steps to analyze the gathered data, taking into account Conversational Analysis and Transactional Analysis. These steps were:

1. Selecting the crossed transactions.

2. Identifying my learners' linguistics choices and positionings.

3. Interpreting the two analyses (Conversational Analysis and Transactional Analysis)
4. Establishing the preliminary categories.

5. Refining the category.

\section{Results from Conversational and Transactio- nal Analyses}

After developing the analysis of both the Conversational Analysis and Transactional Analysis, I came to the conclusion that the most frequent crossed transactions were the following:

a) Crossed transactions in which the participants expressed their nonconformities by saying literally "not", especially during the development of an English task. For example, "I do not understand English" or "Neither do I know how to say it nor how to explain it."

b) Crossed transactions in which some group members became somewhat authoritative during the development of a task. For example, when a peer insisted on how an activity should be developed in group.

c) Crossed transactions in which some group members did not maximize the use of the time to develop an activity in group. For instance, when a learner suggested that they start the activity instead of playing with their cell phones.

d) Crossed transactions in which some group members did not take action during the group activity and their silence was in itself a response. For instance, when a person asked who should write the answers of an activity and the group members did not answer.

After identifying the four crossed transactions, I noticed that these tended to become Complementary Transactions in the sense that the group members tried to reshape their positionings and contribute to the development of the project.

The following table illustrates the three types of crossed transactions and the positionings that emerged from these transactions after analyzing the main data collection instrument, the audio recordings: 
Taking into account the nature of the activities and their school and social skills, the learners assigned responsibilities among the members of each group. The rights and responsibilities to participate in group activities were given, in most of the cases implicitly, according to the manner by which my learners acknowledged their school and social skills. Based on this conclusion, I identified a single category which I called: EFL University Learners' Structures of Participation Framed by Reciprocal Acknowledgment of Their School and Social Skills.

\section{EFL University Learners' Structures of Participation Framed by Reciprocal Acknowledgment of Their School and Social Skills}

This single category summarizes my learners' patterns of behavior and discourse upon recognizing implicitly or explicitly their classmates' skills when participating in group activities. The skills recognized by the group members were related to (a) checking each others' work in English, (b) building consensus among peers, and (c) guiding the development of the task and helping assign responsibilities.

Table 2. Crossed Transactions and the learners' positionings

\begin{tabular}{|l|l|}
\hline \multicolumn{1}{|c|}{ Crossed transactions } & \multicolumn{1}{|c|}{$\begin{array}{c}\text { Positionings that emerged from the } \\
\text { crossed transaction }\end{array}$} \\
\hline $\begin{array}{l}\text { 1. Crossed transactions during the comprehension and } \\
\text { development of an English task in group. }\end{array}$ & Knowledgeable Learner in English \\
\hline $\begin{array}{l}\text { 2. Crossed transactions during the process of making } \\
\text { agreements in group. }\end{array}$ & Consensus Builder \\
\hline $\begin{array}{l}\text { 3. Crossed transactions during the process of starting a a } \\
\text { task and/or during the assignment of responsibilities } \\
\text { in a group task. }\end{array}$ & Task Initiator \\
\hline
\end{tabular}

The three positionings corresponding to each skill mentioned above were labeled as: Knowledgeable Learner in English, Consensus Builder, and Task Initiator.

Through conversation, my learners situated themselves and their peers with particular rights and obligations as group members in the activities. The following table illustrates the learners' positionings, actions and category that answer the main research question of this study: How do EFL University students position themselves and their classmates as members of a group in a Collaborative Learning environment?
In order to understand how this positionings emerged from the data, I will explain each one by using some samples and by showing which analytical tools from Conversational and Transactional Analyses I employed during the exploration of positionings and participation structures. The three positionings are explained as follows.

\section{Knowledgeable Learner in English}

Analyzing the individual conferences, I concluded that the learners who knew more English or had previous experience as English learners were recognized as valuable peers for the 
group learning process and for the development of the tasks. Another characteristic of this positioning is the way these students helped their classmates. In each group, there was a learner who used different strategies to try to help others better understand English.
I found that my students helped others by encouraging their classmates to pronounce, asking questions about grammar use, repeating instructions or knowledge to verify that the others really understood the task, showing examples or materials (dictionaries, book and notebooks) to clarify questions, or by

Table 3. Learners' positionings, actions and category

\begin{tabular}{|c|c|c|}
\hline Learners' positionings & Actions & Category \\
\hline $\begin{array}{c}\text { Knowledgeable learner in } \\
\text { English }\end{array}$ & Checking others' work in English & $\begin{array}{c}\text { EFL University Learners' } \\
\text { Structures of Participation } \\
\text { Framed by Reciprocal } \\
\text { Acknowledgment of Their } \\
\text { School and Social Skills }\end{array}$ \\
Task initiator & $\begin{array}{c}\text { Guilding consensus among peers } \\
\text { Guing the development of the task and } \\
\text { helping assign responsibilities }\end{array}$ & \\
\hline
\end{tabular}

giving specific explanations of some grammar structures. It is important to note that none of these knowledgeable learners bragged of being a high achiever in English. To the contrary, they were very supportive. This finding reveals that a group member may not always switch to individual mobility when it offers better prospects for status enhancement. This characteristic was found in Boen and Vanbeselaere's (2001) study about social identity. However, in this research, the Knowledgeable Learners is English did not express a desire to change to another group in which they could have a better status working with similar high achievers in English.

In regards to this positioning, there was only one case in which a group member considered he was not being heard when he explained a task in English. His peers told me he used a lot of English in class and the communication broke down because they did not understand him when he talked. They did not mention he was bragging. Their comments were more related to his excessive use of English in group activities. The following samples were taken from the individual conferences and correspond to the previous described situation:

“... cuando no entendían alguna palabra en inglés, me pedían ayuda, sin embargo hay veces que les vale cinco mi opinión o que se enfadan porque se les dificulta pronunciar una frase en inglés, yo entiendo todo eso, porque a mí también me pasa, es de paciencia y de poner toda la energía al inglés."

(Group \#5. Sample 3. CC (initials of a male student), individual conference)

Translation: "....when they [peers] did not understand some words in English, they ask for some help. However, sometimes my opinion does not matter to them and they get angry because it is difficult to pronounce English sentences. I understand it because it happens to me. It is a matter of patience and putting forth a complete effort to learn English." 
In this sample, CC argued that when his group members did not understand a word in English, they asked him for help. However, he felt that sometimes his opinion did not matter to LR and JF (two female students) who got angry because it was difficult for them to pronounce English sentences. He concluded that he understood their reactions because he had felt the same. He affirmed that it was a matter of patience and putting forth a complete effort to learn English. In the following sample, JF talked about the difficulties she noticed during the group work.

"En el grupo se presentaron dificultades, uno por no atender a las indicaciones dadas. Otro de los motivos fue la diferencia que existía entre cada uno de los integrantes en cuanto a carreras y al manejo del idioma."

(Group \#5. Sample 8: JF (initials of a female student), individual conference)

Translation: "In the group, there were some difficulties. First, we do not pay attention to the instructions, secondly, the difference of our majors, and English knowledge."

In this sample, JF mentioned that they had difficulties. From her point of view, this happened because (i) they did not pay attention to the instructions, (ii) their skills were different according to the major they were enrolled in, and (iii) their individual English knowledge. In this group, I noticed that there was a difficulty when they had to distribute the tasks. I concluded that they divided the tasks according to the skills they acknowledged mutually. Thus, CC who was studying Graphic Design was good at drawing and illustrating, LR who was studying Law was good at writing and reading, and JF who was studying Engineering was better at organizing the steps of each task. In regards to the audio recordings, I observed that the person who used more commands in group work was JF, the person who answered any question asked by any group member was CC, and the person who listened to the others was LR. She wrote in the majority of the writing activities and was mainly corrected by CC. When CC tried to correct JF, she did not pay attention to him and continued talking. She was one of the group members who was more resistant to change her positioning.

In this group, FJ also used more Spanish than her group members used. As in Nausa's study (2009), one of the important influences in the emergence of the communicative strategies was the influence of students L1, Spanish. However, in this group of students, Spanish and English both were power tools in the sense that $\mathrm{JF}$ and $\mathrm{CC}$ each used one language more than the other as a way to inform the other peer that the linguistic code of communication could be bilingual. This means that if a peer asked in English what they should do, the answer could be in Spanish. JF was not a low or high achiever in English. Her excessive use of Spanish in group activities commonly emerged during interactions with CC who spoke English fast and who did not easily understand the instructions in Spanish or English.

In the individual conferences, I talked to the students who were identified as Knowledgeable Learners in English. I found that in each group there was a person who knew more English than the others. These students agreed with the assigned positioning and argued that it was important to help their peers in a modest way in order to generate a good learning environment. The following samples taken from the individual conferences illustrate what I have mentioned above in regards to the acceptance of this positioning by the group members:

"Primero miramos el número de temas que nos tocaba exponer y después los dividimos teniendo en cuenta cuál era el punto más fuerte de cada uno de los integrantes y por últimos nos reunimos para unir toda la información 
y darnos nuestro respectivo feedback especialmente en lo de inglés. (...) Si, ellos creían que mi punto más fuerte era el inglés."

(Sample 2: CB (initials of a female student), individual conference)

Translation: "First, we saw the number of topics that we had to present and then we divided them, taking into account the skills that the group members had, and finally, we got together to consolidate the information and gave each other feedback about the English tasks. (...) Yes, they thought that my strength was to know English."

For this study, being a modest person is very positive in the sense $\mathrm{s} / \mathrm{he}$ is not usually talking about or making obvious his/her abilities and achievements. A modest person also tries to help others learn and interact during group work.

\section{Consensus Builder}

Learners as Consensus Builders can cooperatively share the floor, recognizing not only the other's right to speak but also the validity of the other speaker's opinions. This positioning is democratic because there is an assumption of an equal right to participation in a conversation, making it a positive positioning that can promote solidarity and negotiation.

As an example of this, the following transcript illustrates the view of one of the participants in regards to the need of reaching consensus among the group members:

"Durante el proyecto en todo momento puse en práctica distintas formas de comunicarme con mis compañeros. Porque siempre hubo un trabajo en equipo en donde teníamos que participar y así mismo escuchar la opinión de nuestros compañeros."

(Sample 10: AP (initials of a male student), individual conference)
Translation: "During the project I put into practice different ways of communicating with my classmates. There was always team work in which we had to participate and at the same time we had to listen to the opinions of our classmates."

This positioning may be classified as an Adult from the perspective of Transactional Analysis. This means that the verbal manifestations of this positioning are related to the question-answer process that has a direct and clear intention (De Miguel, 2006). Sentences such as "Who selects this one?" and "Do we know what we have to do?" were found in the transcriptions during peer interaction, and they were also repeated and explained by the participants in the individual conferences.

Not only in the transcripts but also in my teacher field notes, I noticed that AN expressed an interest in knowing what his peers thought about the activities or topics by asking questions such as "What do you think of this?" or "Any other idea?" He rarely addressed these questions to a specific person; but rather to his group as a whole. From Conversational Analysis, the adjacency pairs (two utterances by two speakers) were question-answer-agreement. Peer questioning was a characteristic of the turn-taking in which the Consensus Builder used polite expressions.

A Consensus Builder is the peer who helps make decisions in group by promoting negotiation or problem solving among peers. This positioning may be connected with the Adult Ego State and is exemplified with sentences such as "What do you think?" and "Do you agree on that?" However, it is important to clarify that the ego states, including the Adult Ego State, may be "contaminated" by other states depending on the situation and context. This means that a transaction may present different directions of positioning: a speaker may be classified as a Parent due to 
his/her desire of helping others excessively, and then the same person may behave as an Adult after reflecting upon his/her excessive sense of protection. In this particular case, the Consensus Builder is characterized by his/her interest in maintaining neutrality; however, it highly depends on the group members' perception of equality, especially when some group members do not have the same time availability as others to develop the task outside the classroom.

In this study, reaching consensus depended on how important this process was to the following sample shows the perception of one student in regard to the process of reaching consensus at the moment of dividing the activities:

\begin{abstract}
"Nos dividíamos los temas de acuerdo a las habilidades de cada uno y de acuerdo con qué tema nos sentíamos más cómodos y conformes para que no fuera una dificultad ni un problema el desarrollo de las actividades."
\end{abstract}

(Sample 6: DS (initials of a male student), individual conference)

Translation: "We divided the topics according to our skills and the topic we felt more comfortable with so that there was no difficulty or trouble in the development of the activities."

As in the Malaver's research (2007), I found that there was a constant seeking of consensus among peers during the activities, and that peer interaction was the medium which led students to apply skills related to negotiation. In her research, Malaver argues that peer interaction allowed the students to recognize the positionings their peers assumed for their individual learning process. Our students constantly recognize their positionings and those of their peers' and then decide if they respect them and acknowledge their skills in group.

In this study, the Consensus Builders tried to help their group members become participants during the decision-making process and to generate a collaborative learning environment. In this sense, the concept of participation as a freedom of choice is pertinent. It is not only related to the right to participate effectively in a given space but also the right to define and shape that space and the scope for possible actions within it (Gaventa \& Jethro, 2010). Through consensus, the right to define and shape the course of an action is possible.

\section{Task Initiator}

The positioning of Task Initiator emerged from different samples of the data that revealed some influence on behavioral changes during the development of the task in the group activity. As Webb (2008) argues, individuals do not always have the same opportunities for participating in groups. Some group members are more active and influential than others. According to this author, personality characteristics such as extroverted, high-status students such as high achievers, social characteristics such as race and gender, or peer status characteristics such as being popular may determine the member's relative influence in the group.

The next transcript was gathered through audio recordings. The group members were 2 male learners and 1 female learner. The activity was the same as what the previous group was developing: to agree on which two activities they wanted to design in order to present five words. After agreeing on the selection of the words, they assigned some responsibilities to work at home.

In this sample, AP positioned himself as a Task Initiator (lines 36, 37 and 38). Although JD adopted two new positionings, which I will call Bossy Peer when giving orders and peers' ideas approver when saying "OK", his positions did not advance because AP refused to validate that positioning. From this sample, I conclude that being a Task Initiator requires the person 


\section{Transcript 1}

\begin{tabular}{|c|c|c|}
\hline \multicolumn{2}{|r|}{ Transcript } & Translation \\
\hline $\begin{array}{l}34 . \\
35 . \\
36 . \\
37 . \\
38 . \\
39 . \\
40 . \\
41 . \\
42 . \\
43 .\end{array}$ & $\begin{array}{l}\text { JD: Coloque::e. Los correos, igual, nos las } \\
\text { pasamos. (referring to the selected words) } \\
\text { AP: Pero, ¿porqué no anotamos cada cual el } \\
\text { correo?, y ¿quién se queda con esta hoja? } \\
\text { ¿Para qué anotamos acá? } \\
\text { (Silence) } \\
\text { EM: ¿Se la queda? } \\
\text { JD: Ahorita nos pasa las palabras. } \\
\text { AP: ¡A:h! Se las sabe y no anota de una vez. } \\
\text { JD: Bueno. }\end{array}$ & $\begin{array}{l}\text { JD: Write down. Write down the } \\
\text { e-mail addresses. Anyway, we will } \\
\text { contact each other. } \\
\text { AP: But... why don't we each write } \\
\text { down our addresses? And who will } \\
\text { take this piece of paper? } \\
\text { EM: Would you? } \\
\text { JD: You'll pass us the words. } \\
\text { AP: ¡A:h! You know them and you } \\
\text { do not write them now. } \\
\text { JD: OK. }\end{array}$ \\
\hline & $\begin{array}{l}\text { Taken from Audio recordings. } \\
\text { Transcript \#1: 07/09/2010, lines 34-43 } \\
\text { Group \# 6: Men: JD and AP. Woman: EM }\end{array}$ & \\
\hline
\end{tabular}

to have some discursive strategies, such as questioning before ordering so that decisions are made in concordance with the task and the group members' interest.

At the end of this transcript, JD accepted the two simple but obvious reasons given by AP in line 42. The crossed transaction in this sample may be defined as an Adult and Child (AP - JD) in lines 42 and 43 in the sense that AP positioned himself as a strategist who tried to maximize the time and expressed his disagreement in regards to his classmates' order. JD accepted AP's exclamation. Accepting a positioning, as in this case, does not require the establishment of elaborate reasons during the development of a task. Positionings can be shaped after providing simple reasons.

In the individual conference, AP explained to me that he tried to guide the task in class as a way of avoiding any kind of risk in which his group members might try to control his time by sending e-mail messages without negotiating previously. As in the positioning of Knowledgeable Learner in English (DC), these students did not want to assume more responsibilities than they already had. They tried to maximize the use of their time in class by helping their peers without taking the risk of doing more than they had to do.

AP as a Task Initiator may be categorized as a leader who uses initiative, shows responsibility, respects his peers, and listens to the others. JD also may be categorized as a leader; however, his use of imperative forms (e.g. write down and pass them) might affect his position as a leader and cast him instead as a bossy peer who only gave orders. The initial complementary transaction changed into a crossed transaction with a direct comment-answer adjacency pair (two utterances given by two speakers). Then, this crossed transaction became complementary once again.

A Task Initiator is the peer who promotes reflection, especially at the beginning of an activity, about the way the group should develop its task. This positioning is characterized by the continuous peer questioning and the use of ordinary numbers to organize the steps of the task; for example, "What do we do first, secondly, etc.?" In this study, a Task Initiator is successful when $\mathrm{s} /$ he asks concrete questions and provides clear ideas. This means that this person tries to achieve a balance between the processes of questioning 
and brainstorming for the development of a group activity. This person also tries to make others participate and maximize the time spent in class. This positioning is the most susceptible to being "contaminated" by the other two ego states because, if the other group members do not collaborate, the Task Initiator may become a Parent who confronts his/her peers repeatedly, especially by giving orders, or a Child who gets stressed and abandons the leadership role. In other words, a contaminated positioning refers to one that has adopted conflicting characteristics of other positionings that may compromise the validity of the discourse of this person.

In this positioning, I would say that there was a transition of personal identity to a social identity in the sense that the group members accepted being oriented by the Task Initiator and work as a group. According to Korte (2007), this transition from personal identity to a social identity "tends to depersonalize the individual in favor of becoming a group member" (p. 169). From his view, it is a neutral description of the process of downplaying personal attributes in favor of acquiring those that belong to the group. This process of downplaying personal attributes does not mean a loss of personal identity but rather "the acquisition of an additional identity" (Korte, 2007). Working strategically is not an easy task. However, peers notice that if they have a plan to work as a group, they can develop a task more easily, better and faster. After this analysis, I am able to conclude that acquiring a social identity is the result of accepting the positionings that promote working and learning strategies.

A Task Initiator can also help the group assign activities according to their time availability, abilities, and interests. I noticed that as soon as the Task Initiator selected a task, the rest of the group members started to select their own tasks. I also realized that the choice of responsibilities was governed by the group members' abilities to write in English, synthesize ideas and diagram or illustrate concepts through drawings. They related the task assigned with the major they were studying. For example, the learner who studied Graphic Design chose the activities that required creativity, knowing implicitly that these were not going to be selected by the other group members.

In the following sample taken from the individual conference, AN explained how the group members distributed the responsibilities in order to develop a group activity. AN was a Task Initiator who asked question as a strategy to guide the development of the task. In his comment, he recognized the group made decisions about the task assignment taking into consideration the skills that each group member had.

\begin{abstract}
"Nosotros comenzamos a distribuirnos las tareas por decisión de cada uno ya que si uno quiere hacer un tema específico lo hace porque tienen mayores habilidades en hacerlo."
\end{abstract}

(Sample 7: AN (initials of a male student), individual conference)

Translation: "We started distributing the duties based on our own decisions because if we want to develop a specific task it is because we have specific skills to do it."

This positioning was also characterized by the need for initiating the tasks with the approval of each group member. In most cases, the Task Initiator tried to reach consensus, and thus each group member was responsible for each duty. In the next transcription taken from an individual conference, $\mathrm{PH}$ highlighted the importance of having the opportunity to choose a duty at the moment of starting the task. Generally, the Knowledgeable Learner in English was the leader who checked the others' tasks and put together the information. 
"Para iniciar el trabajo, cada uno seleccionaba lo que quería hacer, dando también la posibilidad de elegir y, a continuación enviamos la información a la persona encargada de organizarlo."

(Sample 14: PH (initials of a female student), individual conference)

Translation: "In order to develop the task, each one selected what they wanted to do. We also allowed the possibility to choose and then we sent the information to the person in charge of organizing it."

The group members recognized who could develop a specific English task according to his/ her cognitive skills. The positioning that was more related to these skills was the Knowledgeable Learner in English. For example, the group member who was good at reading and writing in English was recognized by his/her peers as a reliable learner who could correct mistakes and provide feedback to the others. After analyzing the individual conferences, I concluded that this positioning was more accepted if the person did not brag of his/her skills. In other words, this positioning had more impact on the group dynamic if the group members felt comfortable at the moment of being corrected and instructed by this learner.

To conclude, the three previously described positionings share characteristics consistent with their possible connection to corresponding ego states. For example, they are more related to the ego state of the Parent and Adult than to the Child. This does not imply that they are not at all related to the Child Ego State because the three ego states are part of a unit; but pertaining to the analysis of this study, the Child Ego State was mainly identified in one group in which three of the four members shared interests and time in other subjects. Based on the analysis, I consider that the Child Ego State can become more spontaneous if the group members share other academic spaces, interests and experiences. This means that when a group member (1) feels more confident using the same "language" as his/her peers and (2) feels $\mathrm{s} / \mathrm{he}$ is less criticized by the others, $\mathrm{s} /$ he may express more ideas and be freer to say what $\mathrm{s} /$ he thinks, behaving more spontaneously without thinking of the consequences of sharing more than $\mathrm{s} /$ he should in a given moment.

\section{Conclusions}

The conclusions show that (1) the rights and responsibilities during group work were given according to the way the learners mutually acknowledged their skills, (2) the participation structures were characterized by the use of words related to leadership and collaboration, and (3) the responsibilities were divided among the members of the group, mainly taking into account their time availability and skills. The school and social skills recognized by the peers were related to (a) checking each others' work in English, (b) building consensus among peers, and (c) guiding the development of the task and helping assign responsibilities. The positionings that correspond to each of these tasks were labeled as: Knowledgeable Learner in English, Consensus Builder, and Task Initiator.

The emerging category EFL University learners' structures of participation framed by reciprocal acknowledgment of their school and social skills illustrates the way in which my learners recognized how good they and their group members were at checking each others' work in English, building consensus among peers, and guiding the development of the task, and helping assign responsibilities in group activities. These types of acknowledgment helped me respond to the two research questions posed for this study: How do EFL University students position themselves and their classmates as group members in a Collaborative Learning 
Environment? and What do these positionings tell us about peer participation structures?

I also drew on the conclusion that social identity could be shaped if there was a "common language' among the group members. This common language includes shared interests, opinions, and ways of working together, among others. In regards to this idea, Korte (2007) states that "the stronger the similarities within the group and the differences between groups, the stronger the identity of the group" (p. 170). If the group members do not share similarities, they seldom have a social identity that characterizes them as a group. If this is the case, some members could feel the desire to become part of another group.

In most cases, the responsibilities were related to the nature of the academic project. The project required participation from each group member because they had to show individual and collective progress during its development. The responsibilities found in this study were mainly established in group, taking into account time availability and skills.

Learners' group identity was constructed by recognizing their school and social skills as group members. The characteristics of the participants' turn-taking revealed that they recognized their skills more implicitly than explicitly. They accepted the positionings that allowed them to work collaboratively and to fulfill the requirements of the task by making agreements according to the contributions that each group member could make during the development of the project.

In regards to leadership as a characteristic of group work, Rothstein-Fisch and Trumbull (2008) mention a concept that enriches the analysis of this study. They call collectivistic socialization a type of socialization in which learners are linked with each other as a whole. They argue that "leadership appears to come from the desire to contribute to the group rather than to gain individual recognition" (p. 42). I noticed that my learners did not look for individual recognition; in fact, I would assert that they were very interested in helping each other, especially when positioning themselves as Consensus Builders.

\section{References}

Babbie, E. \& Rubin, A. (2010). Essential research methods for social work. Belmont, CA. Brooks/ COLE.

Boen, F. \& Vanbeselaere, N. (2001). Individual versus collective responses to membership in a low-status group: the effects of stability and individual ability. The Journal of Social Psychology. Washington. 141, (6), 765.83.

Burns, A. (1999). Collaborative Action Research for English Language Teachers. Cambridge: Cambridge University Press.

Corbin, J. \& Strauss, S. (2008). Basics of qualitative research. Techniques and procedures to develop grounded theory. London: SAGE Publications.

Creswell, J. (2009). Research design: qualitative, quantitative, and mixed methods approaches. London: SAGE Publications.

Dart, B. (1998). Adult learners' metacognitive behaviour in higher education. In Peter Sutherland. Adult Learning. London: Kogan Page Limited.

De Miguel, R. (2006). Fundamentos de comunicación humana. Alicante: Imprenta Gamma.

Dixon, C.; Durán, R.; Green, J.; Putney, L.; \& Yeager, B. (2000). Consequential progressions: Exploring collective-individual development in a bilingual classroom. In Lee Smagorinsky (Ed). Vygotskian Perspectives on Literacy Research. Constructing Meaning through Collaborative Inquiry. Cambridge Cambridge University Press.

Engel, R. \& Schutt, R. (2009). The practice of research in social work. London: Sage Publications.

Gaventa, J. \& Jethro, Pettit. (2011). Power and participation. Political and Civic Leadership. City: Sage Publications.

Harré, R. \& Moghaddam, F. (2003). Introduction: The self and others in traditional psychology and in positioning theory. In R. Harré and F. Moghaddam (Ed.). The Self and Others: Positioning Individuals and Groups in Personal, Political, and Cultural Contexts. 1-12. Connecticut: Praeger Publishers. 
Hayes, J. (2002). Interpersonal skills at work. New York: Routledge.

Hutchby, I. \& Wooffitt, R. (2008). Conversation Analysis. Massachusetts: Polity Press.

Janssen, T., Braaksma, M., \& Couzijn, M. (2009). Self-questioning in the literature classroom: Effects on students' interpretation and appreciation of short stories.L1 - Educational Studies in Language and Literature, 9, 1. 91-116.

Johnson, K. (2002). Understanding communication in second language classroom. Cambridge: Cambridge University Press.

Korte, R. (2007). A review of social identity theory with implications for training and development. Journal of European Industrial Training. 31. 3. p.

Malaver, C. (2007). Analyzing students' critical thinking skills in the process of solving problems through peer interaction. Unpublished master's thesis, Universidad Distrital Francisco José de Caldas, Bogotá, Colombia.

Miller, E. (2007). Learning English, positioning for power. In Miguel Mantero (Ed.). Identity and Second Language Learning: Culture, Inquiry, and Dialogic Activity in Education Contexts. Charlotte: IAP.

Mortensen, K. (2008). Instructions and participation in the second language classroom. A Dissertation Submitted to the University of Southern Denmark in Partial Fulfillment of the Requirements for the Degree of Doctor of Philosophy. Institute of Language and Communication.

Nausa, R. (2009). Analyzing conversation strategies among Colombian EFL learners. Unpublished master's thesis, Universidad Distrital Francisco José de Caldas, Bogotá, Colombia.

Parrott, G. (2003). Positioning and the emotions. In Rom Harré and Fathali Moghaddam (Ed). The Self and others: Positioning individuals and groups in personal, political and cultural contexts. Westport: Praeger Publishers.

Rothstein-Fisch, C. \& Trumbull, E. (2008). Managing diverse classrooms: How to build on students' cultural strengths. Alexandria, VA: ASCD.

Seedhouse, P. (2004). The interactional architecture of the language classroom: A conversation analysis perspective. Malden, MA: Blackwell.

Smith, B. \& MacGregor, J. (1992). What is collaborative learning? In A. Goodsell, M. Maher, V. Tinto, B. Smith \& J. MacGregor. Collaborative learning: A sourcebook for higher education. National Center on Postsecondary Teaching, Learning, and Assessment, University Park, PA.

Stauffacher, M.; Walter, A.; Lang, D.; Wiek, A., \& Scholz, R. (2006). Learning to research environmental problems from a functional socio-cultural constructivism perspective: The transdisciplinary case study approach. International Journal of Sustainability Higher Education: Organizing sustainability learning Bradford. 7, (3), 252-275.

Stoller, F. (2002). Project work: A means to promote language and content. In Jack C. Richards and Willy A. Renandya. Methodology in language teaching. An anthology of current practice. Cambridge: Cambridge University Press.

Webb, N. (2008). Learning in small groups. In Thomas Good (Ed). 21st century education: A reference book. London: Sage Publications, Inc.

Weisberg, M., \& Weisberg, I. (2002). Guidelines for using Transactional Analysis in clinical social work. In Albert R. Roberts and Gilbert J. Greene. Social workers' reference. Oxford: Oxford University Press, Inc. 


\section{Annex 1:}

In the individual conferences I included some learners' reflections about the class and group work, some transcripts that were analyzed with the participants, and the preliminary positionings I had found in the audio recordings.

\section{DC}

"A la hora de distribuir las tareas solo queriamos ser equitativos con el trabajo ya que de esta manera habría responsabilidades, y cada uno seria parte equitativa del desarrollo del proyecto, pero siempre tratábamos de ayudarnos entre sil para que el desarrollo del proyecto fuera optimo, siempre tuvimos tareas delimitadas'

"Las estrategias comunicativas que tendré en cuenta para los próximos trabajos en grupo serán mejorar el dialogo y siempre estar dispuesto ayudar a mis compañeros y estar comprometido con todas las actividades para el buen desarrollo del trabajo en grupo

\section{(Second part)}

Lee la siguiente transcripción tomada de una de las conversaciones en tu grupo.

(Transcripción \#1: 07/09/2010, líneas 54-75) Grupo \# 1

\begin{tabular}{|c|c|}
\hline 54 & DS: ¡Harmful! \\
\hline 56 & DC: „Harmful! Harmful. \\
\hline 57 & DS: Here, observa a la derecha (pointing out the \\
\hline 58 & phonetic symbols in the computer). \\
\hline 59 & DC: ¿Qué? \\
\hline 60 & DS: No suena, no suena la $\mathrm{ft} /$. \\
\hline 61 & DC: No, la it/ no suena. Ha.mful. \\
\hline 62 & DS: i/'ha:m.fal/! \\
\hline 64 & AH: ¿/ha:m.fol/? \\
\hline 65 & DC: i//ha:m.fal/! \\
\hline 66 & (silence) \\
\hline 67 & AH: Pero \\
\hline 68 & DC: Depende. Depende. \\
\hline 69 & AH:Mmmm. \\
\hline 70 & DC: Harmful and harm (reading the word from \\
\hline 71 & the online dictionary) \\
\hline 72 & DC: Yo creo que es harm, \\
\hline 73 & DS: Yo creo que es harmful. \\
\hline 74 & AH: Hamful, asi, harmful. \\
\hline 75 & (Silence) \\
\hline
\end{tabular}

Posicionamiento: Estudiante conocedor de inglés que actúa modestamente: DC parece conocer los símbolos fonéticos y trata de enseñar a sus compañeros sin posicionarlos como estudiantes de bajo nivel.

Estudiante modesto entendido como aquel que ayuda sin decir que sabe más o sin hacer sentir mal a sus compañeros porque no saben lo que el sí.

THE AUTHOR

AIDA MONTENEGRO holds a BA in English and an MA in Applied Linguistics to TEFL from Universidad Distrital Francisco José de Caldas in Bogotá, Colombia. Her research interests are Discourse Analysis, Waldorf Pedagogy, and Collaborative Learning. 